\title{
4
}

\section{Pulcaracuranie: Losing and finding a cosmic centre with the help of J. G. Reuther and others}

\author{
Rod Lucas and Deane Fergie
}

J. G. Reuther's collecting — of language, myth, material objects, natural history specimens, biographies and Volksgut in general-among the Dieri $^{2}$ and other Aboriginal groups of South Australia's north-east is

\footnotetext{
1 We are especially grateful to Helen Gordon, Reuther's granddaughter, for providing generous access to her personal archive of documents, genealogical records, letters, translations of Reuther's résumé and diary, family photographs and objects (including Pauline's treasured wedding ring). We are equally indebted to the generous support and encouragement of Colin Jericho, grandson of the staunch Kolonist Hermann Vogelsang, whose tenure at Killalpaninna and Kopperamanna exceeded that of Reuther himself. Colin provided us access to his personal archive and outstanding knowledge of all things Lutheran in South Australia. We are hugely appreciative of Anna Kenny for her work on the Reuther manuscript in the South Australian Museum. We would also like to thank the wonderful staff of the Lutheran Archive.

2 There has been a range of renderings of the name for both language and group across time. One of the earliest uses of the form 'Dieri' is the first instructional primer, called Nujanujarajinkiniexa: Dieri Jaura jelaribala (1870), probably written by Koch and Homann, who were members of the second Lutheran missionary expedition that sought to settle at Killalpaninna in early 1868 (Austin 1986: 190; 2015: 4). Missionary Karl Schoknecht compiled Wörterbuch: Deutsch-Dieri \& DieriDeutsch at Cooranina (Cooryanna), in January 1873, together with a Grammatik (Schoknecht and Schoknecht 1997). Missionary Johannes Flierl revised the orthography and wrote a detailed grammar during his time at the mission from 1878 to 1884 . His Christianieli Ngujangujara-Pepa Dieri Jaurani (1880) is a translation of the Lutheran catechism, epistles and gospels in the new orthography. This orthography remained the standard for all mission writings (published and unpublished) until the mission closed in 1915. Reuther and Strehlow employed the same orthography in their translation of the New Testament, as did Reuther, including in his four-volume dictionary (Austin 1986: 176). The mission (and Reuther) adopted the spelling 'Diari', although Siebert— the 'bush' missionary and
} 
comparable with Carl Strehlow's pioneering work among the Western Arrernte. Reuther's unpublished handwritten 13-volume 'The Diari' (1899-1908) ${ }^{3}$ in many ways reflects Strehlow's published seven-volume Die Aranda- und Loritja-Stämme in Zentral-Australien (1907-20). Both contain an unprecedented (and unrepeatable) compendium of materials that continue to inform contemporary ethnography, as well as Aboriginal responses to their own country. The two Germans worked together at Killalpaninna on Coopers Creek (now known as Cooper Creek) from 1892 to 1894 , resulting in the first publication of the New Testament in an Aboriginal language (in 1897). They had both been seminarians at Neuendettelsau. ${ }^{4}$

Lutheran missiology since the seventeenth century had emphasised the need to study local languages to preach the Gospel—since the Reverend John Campanius prepared the first known vocabulary of the Amerindian tribes on the Delaware (where Sweden had established its New World colony in 1638), founded the first known Lutheran school on North American soil and produced the first translation of Luther's Catechism in a 'heathen' tongue (Peters n.d.). In his commentary on Psalm 117, Luther had placed language at the heart of his mission:

\footnotetext{
counter ethnographer-used 'Dieri' in the title for 'Sagen und Sitten der Dieri und Nachbarstämme in Zentral-Australien', published in Globus in 1910. 'Diyari' is the rendering developed from Peter Austin's fieldwork carried out in 1974-77 while a postgraduate student at The Australian National University, in the resulting $\mathrm{PhD}$ thesis and in the published A Grammar of Diyari (Austin 1981). Pedagogical materials for the maintenance and propagation of cultural and linguistic heritage produced since 2008 use a practical orthography based on the phonological analyses of Austin (1981) and later works. Contemporary people have chosen to adopt the name and spelling 'Dieri'. In what originated as two competing native claims, the groups Ngayana Dieri Karna ('We the Dieri people') and the Dieri Mitha ('Dieri ground/country') both adopted 'Dieri' as their identity, despite other differences. Later the two groups joined in a combined 'Dieri' native title claim (SCD2012/001, Lander v. State of South Australia) in which Dieri native title was determined by consent in 2012. With that and a subsequent determination, 'Dieri' now has an existence in Australian case law.

3 J. G. Reuther's 13 handwritten volumes are held at the South Australian Museum (SAM) in Adelaide. Their call numbers are SAM AA266/09/1 to SAM AA266/09/13. These volumes are numbered with Arabic numerals (i.e. 1-13), while P. A. Scherer's English translation of Reuther's work of the 1970s uses Roman numerals (i.e. I-XIII). Scherer's translation was made available on microfiche in 1981. See Appendix 4.1 for the titles of the original 13 volumes.

4 Carl Strehlow was admitted to the Neuendettelsau seminary on 1 August 1888. He graduated on 31 August 1891. Having been assigned as a pastor to the Lutheran Church in North America, Strehlow responded to a call from Australia for missionary work at Bethesda. He was ordained at Light Pass in South Australia on 3 July 1892 and immediately appointed an assistant to J. G. Reuther at Killalpaninna, where he arrived on 11 July.
} 
If all heathen are to praise God, this assumes that he has become their God. If he is to be their God, then they must know him, believe in him, and give up all idolatry. One cannot praise God with an idolatrous mouth or an unbelieving heart. And if they are to believe, they must first hear his word and thereby receive the Holy Spirit, who through faith purifies and enlightens their hearts. One cannot come to faith or lay hold on the Holy Spirit without hearing the word first, as St. Paul has said (Rom. 10: 14): 'How are they to believe in him of whom they have never heard?' and (Gal. 3: 2): 'You have received the Spirit through the proclamation of faith.' If they are to hear his word, then preachers must be sent to proclaim God's word to them; for not all the heathen can come to Jerusalem. (L. W. 14: 9, 10, cited in Valleskey 1993: 2)

It is for this reason that Reuther collected (Dieri) words. Vernacular language was a path to a peoples' soul and mimicked the directness of Luther's aim of bypassing theological hierarchy. In line with Neuendettelsau teachings, Reuther, like Strehlow, pursued understanding of Dieri culture, language and belief as a vehicle for introducing his own. He, like Strehlow, was a great philologist. But there are materials in his four-volume 'Dictionary' (encompassing Dieri, Wangkangurru and Yandruwandha) that disclose more than words; there are ethnographic riches that reveal the preoccupations, passions, values and perceptions of a world that few others have recorded from north-east South Australia. ${ }^{5}$

In this chapter, we present Reuther as the ultimate collector with religious intent: he collected objects to find their names and all the words associated with them. He collected language on the basis of a fundamental Lutheran principle that the word of God must be received in the vernacular so that people knowingly and freely (and according to the patterns of their own thought) choose their acceptance of Christian faith.

Although the time and location of his training were suffused with ideas and theories of culture, historical particularism and Volksgeist, there is no evidence that these intellectual currents particularly informed Reuther's practice. In his own words, his secondary education was 'inadequate' and he found seminary training 'difficult'. He was not, we contend, an anthropological theorist or an ethnographer in a post-Malinowskian sense. His was a practical theology of conversion through language, to ensure belief and thus the possibility of resurrection after death. This religious perspective is, we suggest, a critical key for understanding Reuther and his work. 
What he left to us is a remarkable cache of words, facts and objects that, a century later, become especially valuable to contemporary Dieri people under legislative conditions that Reuther could never have anticipated. For him, the Dieri, after all, were a vanishing people.

Where Reuther documented language as a precursor to conversion and salvation, Australian regimens of heritage and native title demand 'collecting' evidence of connection. In those contexts, prior documentation in a written record is highly valued, indeed privileged (Lucas 1996). Where Reuther attended to language, the state, courts and anthropologists working for them are required to address the record and the material trace of a previously oral tradition. Reuther's 'data' become key elements in a new knowledge practice documenting endurance, persistence and reproduction (of Dieri knowledge, social norms and connection to country). By this means, his material is used by contemporary Dieri people to reinscribe meaning in the landscape, rehabilitate connection, repatriate the past and build identity. Of this process, we provide a brief case study. We explore the ways in which a pivotal place can be elucidated using the work of Reuther and others. We reconstruct-through triangulating the records of missionaries, explorers and anthropologists-how a place has been relocated and reinvested with meaning by contemporary Dieri people, drawing on and seeing with the aid of Reuther's earlier records. Pulcaracuranie enfolds philological collecting, the recording of myth, toamaking, the salvage ethnography of a modernist discipline and the hopes and aspirations of a people reconnecting with their land.

\section{J. G. Reuther}

\section{Origins}

Johann Georg Reuther was born on 3 September 1861. He was the eldest of seven siblings who survived childhood, the children of Martin and Anna Barbara (née Riffelmacher) Reuter. All were born in Rosstal, Middle Franconia, near Neuendettelsau, and all were baptised in the LaurentiusKirche in Rosstal. Church records have all Reuther siblings sharing the surname 'Reuter'; the family today does not know when or why the ' $h$ ' began appearing in the spelling of the surname, but presumably some time in J. G. Reuther's generation. ${ }^{6}$

6 Helen Gordon, personal communication. 
Reuther's education was undertaken in Rosstal, but he complains in his résumé of an elderly teacher he had in the upper classes, from whom he did not learn much. School was supplemented by his religious education: 'what was left undone at school was made up for spiritually in the preparatory and confirmation instructions that I received in Rosstal'.? He was confirmed and received into the church at Pentecost in 1875.

Vocationally, Reuther trained as a weaver (his father's trade) until age 22, during which time he also helped manage the family household (which he says became difficult when a younger sister became deaf and mute at age four). On the basis of this domestic difficulty, he was able to defer military training for two years, but was eventually taken into the reserve for military service, which he served at Neuburg on the Danube.

Reuther had known of the mission school (Neuendettelsau) from the age of 15 and long wished to enter it, but was thwarted in this ambition for a number of years. After military service, he returned to Rosstal and worked as a postman, then as a postal assistant in Nürnberg.

An epiphany or 'awakening' (Veit n.d.) came on Christmas Eve 1885:

It was Christmas 1885 when on Christmas Eve I was at the railway station waiting for the arrival of mail trains. Suddenly in the night at 12 o'clock all the bells of Nürnberg were ringing in the holy festival. This affected me so deeply that I thought, if only all people knew about the holy Christ child. I had to weep because of the great joy which has been granted us Christians, but I was also sad because of the sorry plight of the heathens. ${ }^{8}$

With this new vision and determination, Reuther applied to the Mission Institute and was admitted on 2 April 1886.

On strict Lutheran grounds there is no earthly purpose post baptism other than propagation and proselytising of the Christian Gospel. In a sermon on 1 Peter 1, Luther stated that a Christian really had only one reason for continuing to live on this earth after he had been brought to faith in Jesus:

We have no other reason for living on earth than to be of help to others. If this were not the case, it would be best for God to kill us and let us die as soon as we are baptized and have begun to believe. But he permits us to live here in order that we may bring others to faith, just as he brought

7 Reuther, résumé, Neuendettelsau, 24 July 1888.

8 ibid. 
us ... The greatest work that comes from faith is this, that I confess Christ with my mouth and, if it has to be, bear testimony with my blood and risk my life ... in order that others, too, may be brought to faith. (L. W. 30: 30, 31, cited in Valleskey 1993: 2)

This was Reuther's mission, and it filled the whole of his life, except that for several decades the Aboriginal worlds and languages of Cooper Creek were its vehicle—capturing the hearts and mouths that Luther required.

Of his time at Neuendettelsau, Reuther wrote (in the Zusammenfassung that all graduates had to submit before leaving, on the assumption that they may never return):

My stay in the mission school of Dettelsau was partly a difficult one, partly full of blessing for me. Difficult insomuch as I had received unsatisfactory [inadequate] schooling and had to endeavour to make up for what my education lacked; full of blessing insomuch as I with the help of God and that of my tireless teachers, had reached the point where I was to be a servant of the Lord in His kingdom amongst the heathens in Bethesda. For this purpose I sat for my exams beginning on 16th July, 1888, and, God willing, will be inducted and commissioned on 12th August and on 17th September will embark in Genoa. ${ }^{9}$

Two things stand out from the passage: Reuther's prior education was, in his own eyes, academically inadequate, but he worked hard to overcome any deficiency; and he already knew on graduating that he was being sent to Bethesda at Killalpaninna in northern South Australia.

\section{To the north of South Australia}

Disembarking in South Australia, Reuther began a whirlwind tour of Lutheran communities, preached in a number of churches and prepared for ordination. In this brief period he met his future wife, Pauline Stolz née Rechner, the daughter of a pivotal South Australian Lutheran family. ${ }^{10}$ Pauline's first husband, Johannes Martin Stolz, had died three years earlier.

9 ibid.

10 Pauline Stolz née Rechner was the daughter of Gustav Julius Rechner (1830-1900), schoolteacher, cantor, clerk to George Fife Angas (founding chair of the South Australian Company, which was populating the colony with free settlers), pastor, president of the Evangelical Lutheran Immanuel Synod of South Australia and chairman of the Mission Committee, and thus J. G. Reuther's 'boss' (Proeve 1976). Pauline's eldest son, J. J. Stolz, became the general president of the United Evangelical Lutheran Church of Australia, serving from 1925 to 1953. 


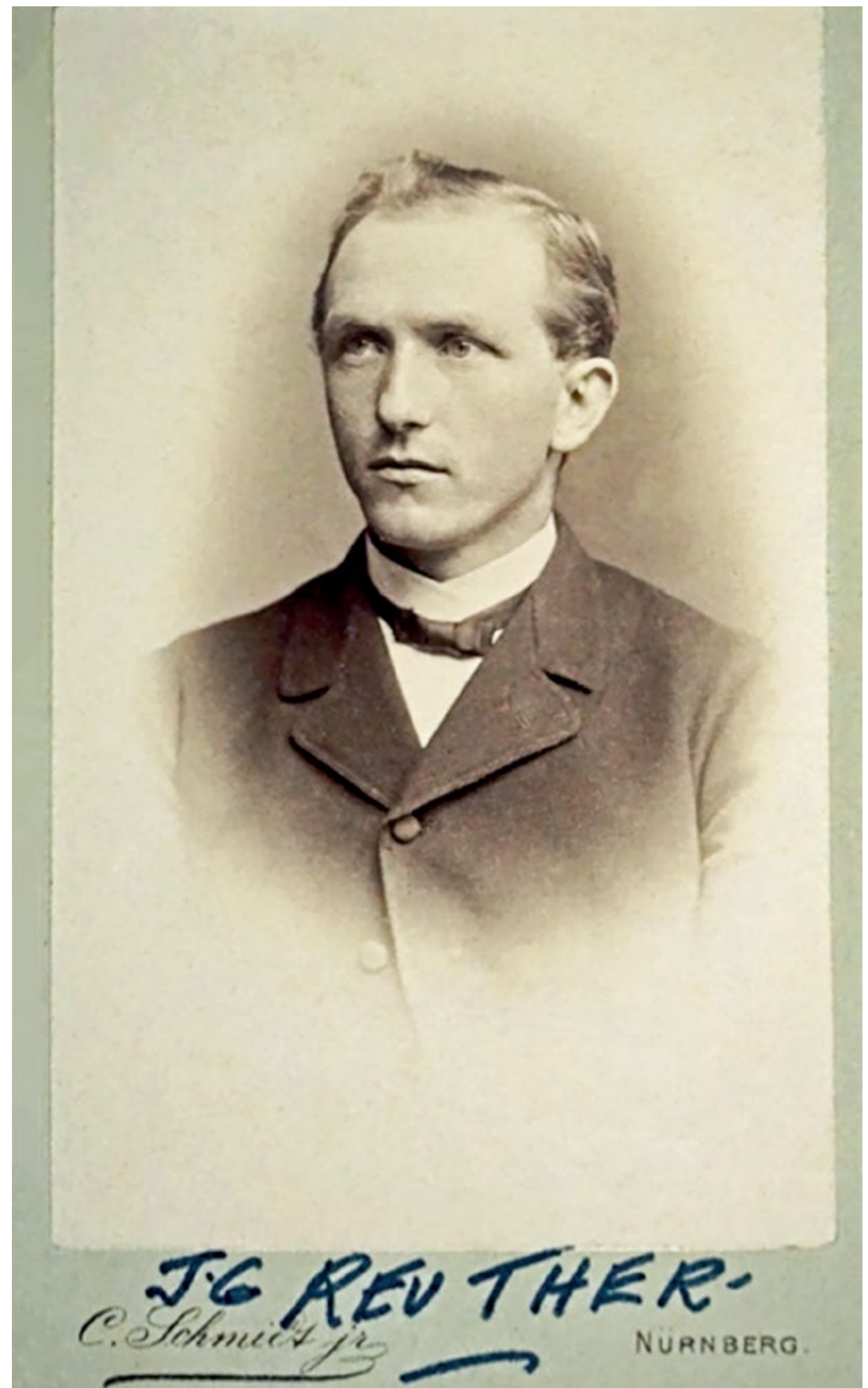

\section{Plate 4.1 Reuther's graduation portrait.}

Source: C. Schmidt, jnr, Nürnberg, 1888. Lutheran Archives, M00313. 


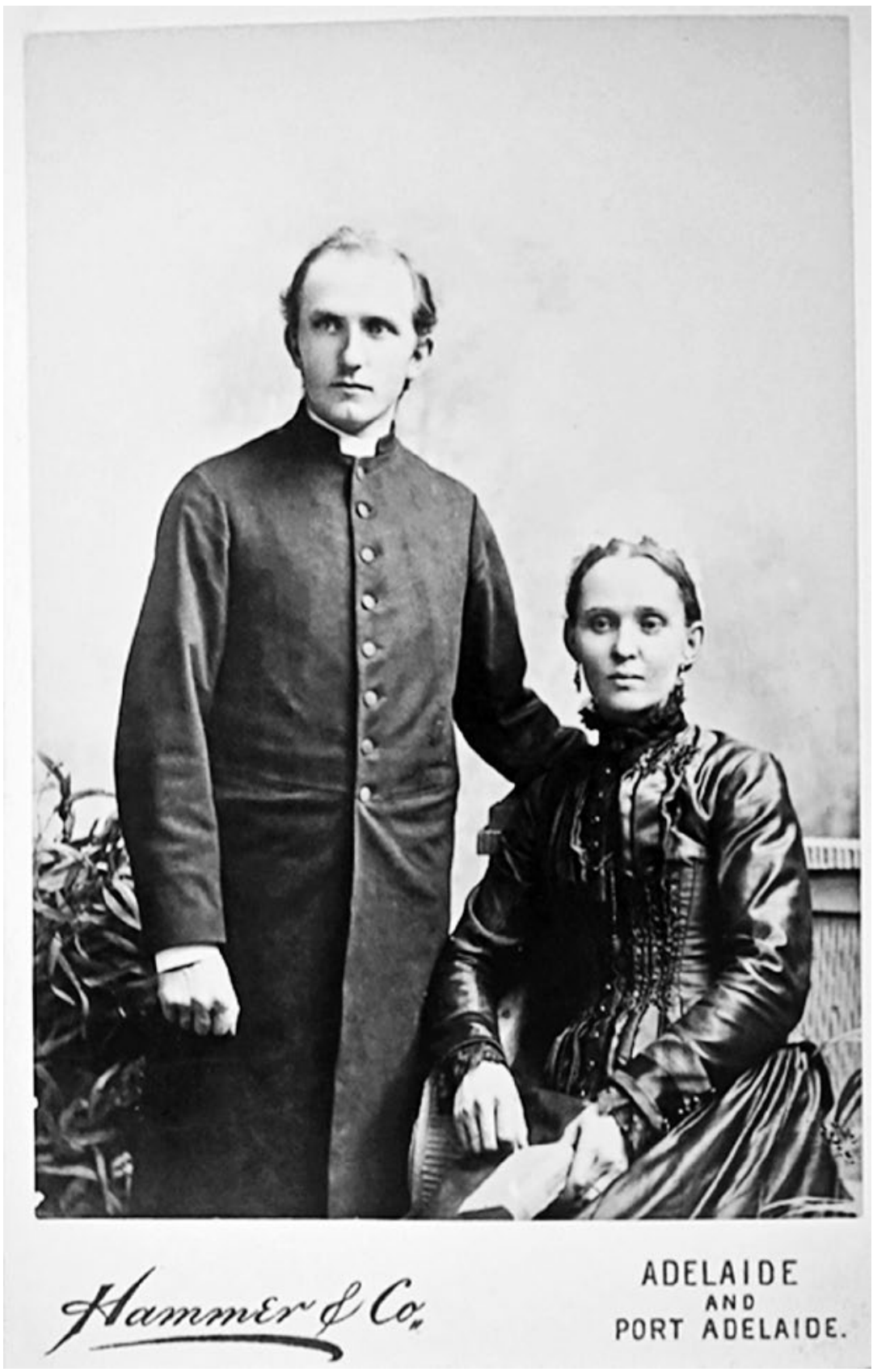

Plate 4.2 Reverend J. G. Reuther and the widow Pauline Stolz around the time of their engagement, 1888.

Source: Lutheran Archives, M00277. 
Pauline and Georg were engaged after an eight-day acquaintance in Point Pass (Reuther 1970: 2), where Pauline Stolz and her three children were living in the church vestry. The engagement was celebrated at Light Pass, where Reuther had gone to be ordained, during a pastors' conference on 23 November 1888, which was also the anniversary of Pauline's husband's death (Reuther 1970: 2). At this strange conjunction, Pauline's father, G. J. Rechner:

mentioned that this day was the day the whole family was in deepest sorrow when my bride [fiancée] was deprived of her husband through death. Today he would also bring joy to the bride ... After this he blessed our union [engagement]. (Reuther 1970: 2)

Five days later (on 28 November 1888), Reuther left Adelaide with Johann Flierl, but without Pauline, on his first trip to the mission station on Lake Killalpaninna, then called Bethesda, arriving on 2 December (Scherer 1966a: 304). He was joined three months later by Pauline, whose first Reuther child was born on the couple's first wedding anniversary; she was to bear a child each year for the next eight years, all at Killalpaninna on Cooper Creek.

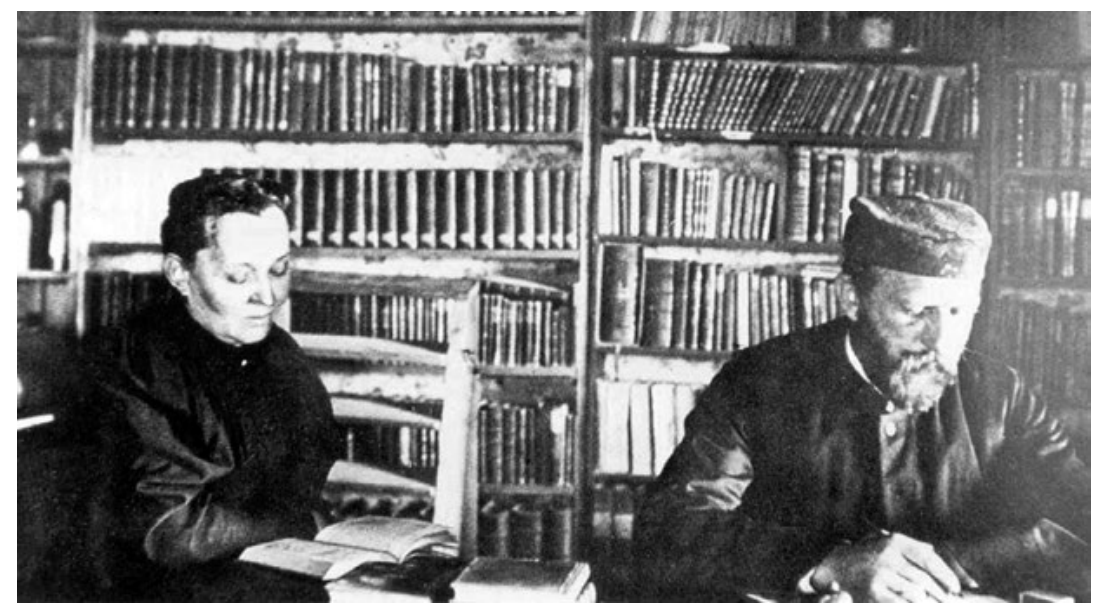

Plate 4.3 Pauline and J. G. Reuther in the missionary's study, Killalpaninna. Source: Lutheran Archives, P027/41/05316.

Although principally taken up with the practical and moral duties of Lutheran Mutterschaft, Pauline was also a helpmate and facilitator of Reuther's work, as epitomised in the frequently used portrait of them together in Reuther's study (see Plate 4.3). This is the room in which 
Reuther worked on the 'Dictionary', the Dieri manuscript volumes and (with Strehlow) the New Testament translation. In his diary, Reuther recorded the 'dedication' of the newly built study on 6 May 1891 . He added:

Give Your blessing, O Lord, to the work I will be doing in this room. Especially send Thy Holy Spirit Who evermore give me the wisdom to study Thy Word, so that it may become a power for me and for the others, the heathen, to save all who believe it. (Reuther 1970)

With the aid of Strehlow, Reuther commenced translation of the New Testament on 10 April 1893 (Scherer 1966a: 305; 1979: 13). Strehlow was transferred to Hermannsburg 18 months later. Reuther's diary records that Strehlow and Reuther left Killalpaninna for Finke on 27 September 1894, arriving at Hermannsburg on 11 October; Reuther stayed five weeks then left on 16 November 1894. During this absence, Reuther's child Georg Edwin died, aged three months. Reuther continued with the translation alone until, on 29 October 1895, he noted on a calendar: 'Thanks to God, today I finished the New Testament in Diari [Dieri]' (Reuther 1970). On 18 November, he added a short preface and continued revising the text and preparing the manuscript until August 1896 (Scherer 1966b: 314). According to Scherer (1979: 13), Reuther 'transcribed the New Testament into Diari three times before he was satisfied with the textual result'. On the debate as to who contributed most to the linguistic work, Scherer (1966b: 314) points out that Strehlow had been at the mission only nine months by the time of commencing the translation, but Reuther had already spent four-and-a-half years learning the language; Strehlow spent less than 18 months assisting Reuther in the task, but the latter spent at least five-and-a-half years on the translation.

G. J. Rechner (Reuther's father-in-law) supervised publication of the Dieri New Testament by G. Auricht of Tanunda, South Australia. This took two years as:

every proof sheet had to be forwarded to Mr. Reuther in the Far North for correction and revision ... The book is likely to remain a monument of piety and industry long after the tribe for which it has been specifically produced is extinct. ${ }^{11}$

11 A new 'New Testament', The Advertiser, [Adelaide], 22 September 1898: 4. 


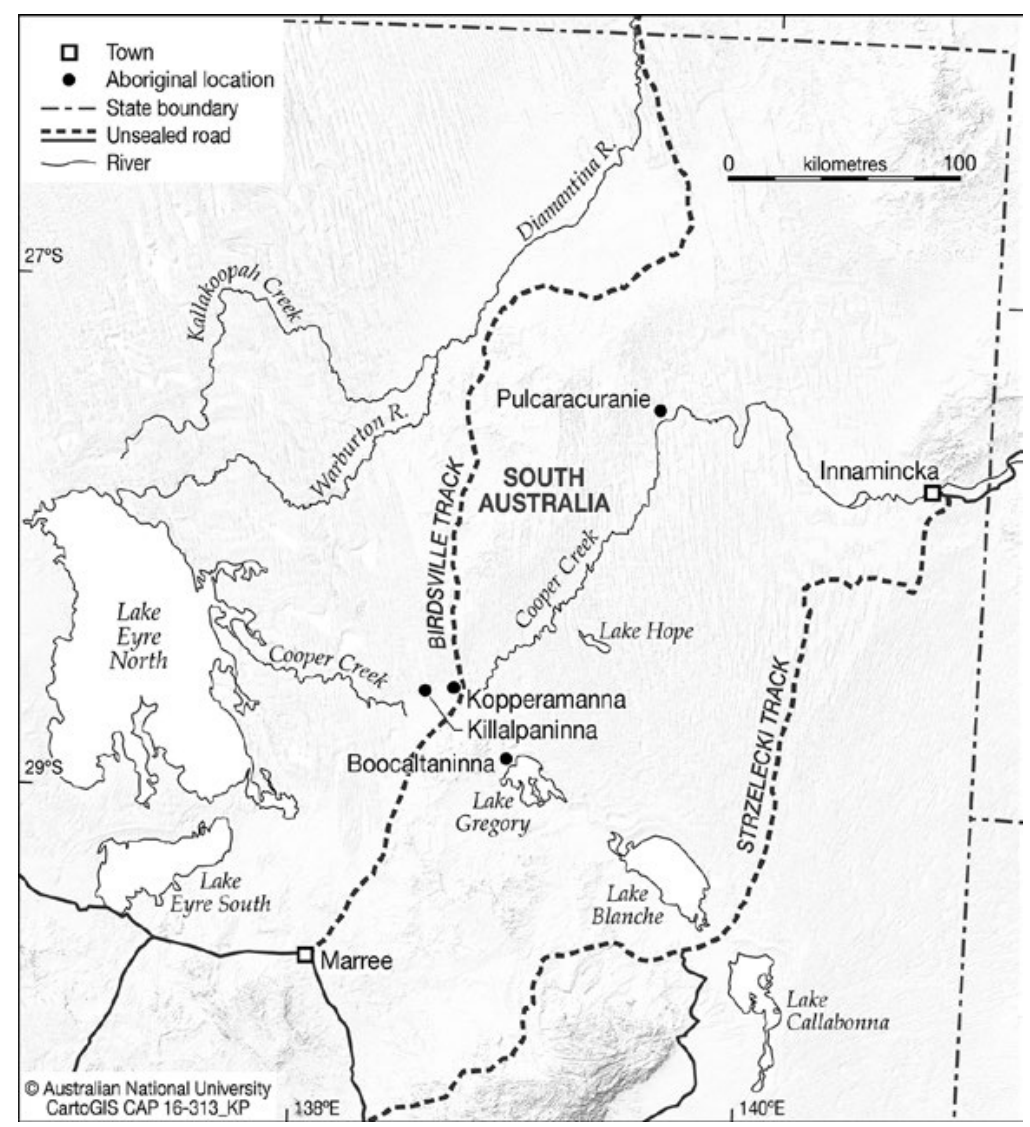

Map 4.1 The location of Lutheran missions in the vicinity of Cooper Creek, northern South Australia.

Source: CartoGIS, The Australian National University.

\section{Collections}

A contemporary account of Reuther's collection around the time of his leaving Killalpaninna is as follows:

The interior of Mr. Reuther's dwelling is a veritable museum. The passage contains over 1,000 pieces of native weapons, ornaments and apparel, including 100 boomerangs, suspended from the ceiling. Four hundred symbols [toas], composed of almost every kind of material available, form an interesting collection. These symbols correspond to European finger posts, and through their agency the blacks indicate to each other the place to which they have gone. ${ }^{12}$ 


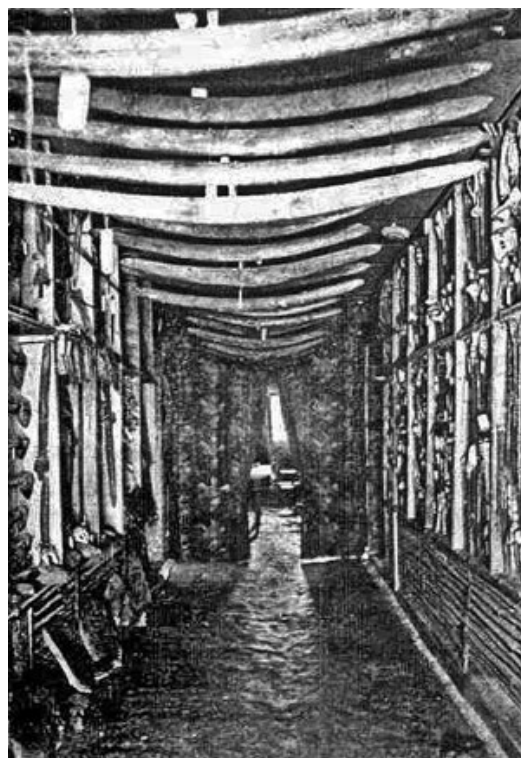

Plate 4.4 The central corridor of Reuther's Killalpaninna house.

Source: Kapunda Herald, 10 May 1907.

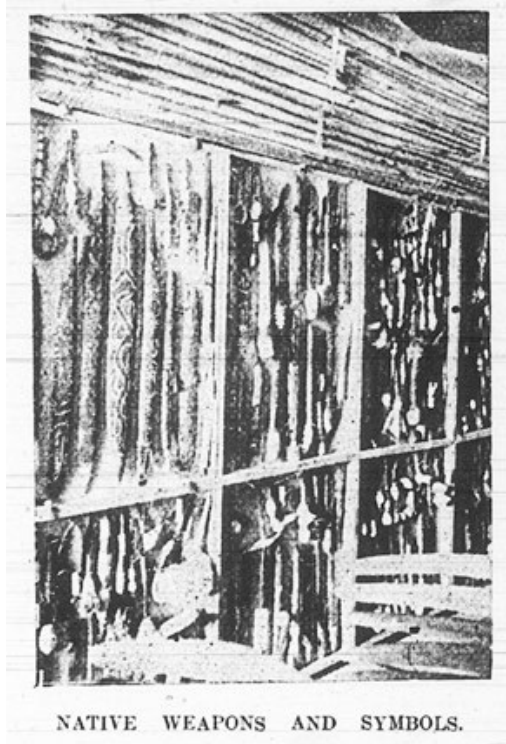

Plate 4.5 Reuther's artefact collection, including toas, in his Killalpaninna house.

Source: Observer, [Adelaide], 10 February 1906.

This collecting subserved Reuther's desire to collect everything that would facilitate access to the Aboriginal mind and thereby act as a medium for its transformation. Reuther collected things to find the words attached to them, along with all their associations. This can be seen in the multilayered entries in the 'Dictionary', which is replete with contextualised renderings, uses, conjunctions and examples.

A. C. H. Zietz, a curator at the South Australian Museum, visited Reuther at his Gumvale property in 1907 'to inspect an extensive ethnological collection made by him at Cooper Creek'. ${ }^{13}$ It was described at the time as follows:

The comprehensive collection represents the results of 20 years' work by an enthusiastic ethnological expert, and includes a vast variety of boomerangs, spears, mats, charms and sacred articles, concerning which little had been hitherto known. There is also over a score of bottles of seeds and roots, which formed a considerable part of the food of the aborigines

13 Museum report, The Advertiser, [Adelaide], 5 November 1908: 12. 
... Apparently Mr. Reuther was always on the alert for new discoveries, and he assured Mr. A. H. C. Zietz ... that once anything was brought under his notice for the first time he never rested until he had gained all the information available in regard to it. ${ }^{14}$

The material culture collection was bought by the museum in October 1907 for $£ 400$ (Scherer 1979: 15).

Seven years later, following Reuther's death, the museum board purchased a set of manuscript ledgers and three maps for $£ 75$ (Scherer 1979). The 'Manuscript' (as it has come to be known) included the fourvolume Wörterbuch ('Dictionary') that Reuther had worked on from 1903 to 1906, a 'Diari Gramatik' he had completed in 1899, together with Wangkangurru and Yandruwantha grammars in 1901 (see Jones and Sutton 1986: 53; Stevens 1994: 211) and wordlists of eight Aboriginal languages, with each having approximately 1,744 single glosses in volume 5, notes on subjects such as Farben ('colours') and Verbote für alle ('general prohibitions') in volume $6,{ }^{15}$ a collection of 2,468 placenames (volume 7), explanations of 303 personal names (volumes 8 and 9), a collection of myths and legends (volume 10), a volume (11) called 'Von der Götter- und Geisterwelt der Eingeborenen Australiens' ('About the world of the gods and spirits of Aboriginal Australians') and two volumes (12 and 13) describing his material culture collection (see Kenny 2017).

\section{A focus on language}

The role of language in the conversion of the Dieri was articulated by Goessling, who was among the first missionaries to settle (unsuccessfully) in Dieri country. ${ }^{16}$ Mission was a 'battlefield' and language was the 'weapon carrier' (Waffenträger) that was to aid the fight:

Die Reise mit Allem, was damit zusammenhängt, liegt jetzt hinter uns. Der Marsch nach dem Kampfplatz ist nun vollendet. Und weil das eigentliche Kriegsleben erst mit dem Ausbruche des Krieges seinen Anfang nimmt, so geht auch fir uns der eigentliche Krieg jetzt erst an. Wir sind nun auf dem Platze, den der Herr uns gezeigt hat, und unter dem Volke, welchem unsere

14 A splendid ethnological collection, Register, [Adelaide], 29 October 1907.

15 The notes in this small notebook are sparse and mainly crossreference entries in the other volumes.

16 Missionary Johann F. Goessling was in the very first party that departed Langmeil for Lake Killalpaninna to found the Bethesda Mission in October 1866, confusingly, originally called Hermannburg. Others included missionary Ernst Homann and Kolonists ('lay assistants') Hermann Vogelsang and Ernst Jacob (Proeve and Proeve 1952). 
Sendung gilt. Jetzt gilt es nun sich zu beweisen als treue Streiter Jesu Christi, denn es wird Niemand gekrönt, er kämpfe denn recht. Und das möchten wir auch gerne, recht kämpfen und keine Luftstreiche thun; denn Luftstreiche ermüden nur, richten aber nichts aus, als daß sie den Kämpfer dem Feind zum Spott machen. Nun kennen wir ja unsere Waffen und wissen auch, wie sie gefítrt werden müssen, wenn wir nur erst den Waffenträger der Sprache in unsere Gewalt hätten. Und es hält oft sehr schwer das richtige Wort fir einen Gegenstand, Begriff oder Bewegung zu bekommen. Man kann oft Stunden lang an einem Worte klauben und kriegt es mitunter doch nicht heraus. Zuerst bekamen wer eine Anzahl Worte von Herrn Gassen (?) in Lake Hope, und nachher haben wir uns, so viel wir eben konnten, dazu gesammelt und suchen so bei Kleinem immer weiter zu kommen. Man mu $\beta$ sich zuerst in ihren Gedankenkreis hineinfinden. ${ }^{17}$

[The journey and everything associated with it is now behind us. The march to the battlefield is completed. And because actual war life starts only with the outbreak of war, so for us the actual war begins only now. We are now at the place that the Lord has shown us and among the people whom our is aimed at. Now it is necessary to prove ourselves as Jesus Christ's loyal fighters, as nobody will be crowned unless he fights well. And that is what we would like, fight well and not beat the air, as beating the air tires only, but achieves nothing other than that it holds the fighter up to ridicule in front of the enemy. Now we surely know our weapons and also know how we must use them, if only we had the weapon carrier of the language under our control. And it is often very difficult to get the right word for an object, a term or a movement. One can often spend hours pondering over//gathering a word and does not find it in the end. At first we received a number of words from Mr Gassen (?) [Police Trooper Samuel Gason] in Lake Hope and later we have collected as much as we could, and seek, little by little, to always progress. One must first acquaint oneself with their body of thought// world of thoughts//way of thinking.]

Language learning was a way of unlocking the 'heathen' mind so that Christ's message could find fertile ground. The study of Aboriginal religion—and Indigenous thought in general—was to service conversion.

The great Lutheran theorist Warneck, in Missionsmotiv und Missionsaufgabe nach der modernen religionsgeschichtlichen Schule (The Missionary Motive and Missionary Commission According to the Modern School of the History of Religion; 1907, cited in Veit n.d.), provided instructions for a theoretical

17 Schreiben des Missionar Gößling an das Missions-Comité, 15 April 1867, Kirchen und Missionsblatt, p. 49. 
comparison of religions, together with a practical apology of Christianity. He proposed that both were required of Lutheran missionaries and both should be taught as part of training. He wrote:

It is not sufficient that the missionary knows Christianity, he also needs to know deeply the Heathen religions which he has been sent to overcome. Before he can confront that religion in discussion, sermon, teaching and literary work, he must have earlier fought the internal context [of the relativity of religions] in his own mind. That demands study. Objects of these studies must be 1) the sacred documents including the most important religious literature which the respective religions possess; 2) the religious traditions where religious sources do not exist; and 3) the religious life and activities as they come presently before our eyes: the religious practices as they can be known from the forms of cults, customs, organisations, sacrifices, prayers, sorceries and, particularly, from their morals. (Warneck 1907, quoted in Veit n.d.: 11-12)

Although written at the end of Reuther's tenure and long after his seminary training, this seems an apt summation of his interests and passionsincluding the collection of what we perceive today as ethnographic details - for the purpose of overcoming heathen belief. Both the knowing and the overcoming - the documenting and the dismissal—were integral to Reuther's vision of an essentially religious, not anthropological, task:

Feeling my way into the mental world of these people I searched through their legends and the god-and-spirit world of heathendom in an attempt to discover points of contact with the Christian faith, and thereby to destroy their pagan concepts. Indeed, it cost me much time and labour to become a Dieri to my Dieri people, for in my opinion a missionary without a thorough knowledge of the language and customs of his people is, in the best instance, like a clock that works but has no hands. (Reuther, quoted in Scherer 1979: 14)

Warneck, in Evangelische Missionslehre: Ein missiontheorestischer Versuch (Evangelical Doctrine: From the perspective of theory; 1897), emphasised the learning of local languages as the means of spreading the word of God (hence the-tautological—need to make the Gospel available in Indigenous languages):

He maintained that since there were no peoples in the world who were speechless, there could also be no people who were without religion. This was evident in the fact that the gospel could be preached in all languages and all languages were capable of Bible translation. (Kenny 2009: 101-2) 
Kenny (2009: 102) says that it is not clear that Strehlow was explicitly taught Warneck's principles on language and religion, but follows Veit by suggesting that it is 'reasonable to assume' a familiarity with these ideas, pointing to the presence of Warneck's pamphlets in the seminary's library (p. 103). This would apply equally to Strehlow's fellow seminarian, Reuther. We do not deny that these ideas were 'in the air', most especially at Neuendettelsau in the late nineteenth century. We do not doubt that they infiltrated Reuther's thought and led to his profound attention to language. But we have found little evidence that this was a theoretical interest per se. While it may represent a missiological 'anthropology' in the broadest sense, it is not an anthropology in the twentieth-century disciplinary sense (of a secular, descriptive or analytic science à la RadcliffeBrown or Malinowski).

Reuther's was not ethnography in the style of a later age. In his diary entry for 11 March 1891, he wrote:

I was field-preacher in the camp near the station. Thou crucified One open their hearts, that Your anxiety and pain not be in vain for them. $\mathrm{O}$ Lord of the harvest see that many are not lost. Open Thou their hearts that they may take heed of Thy word. (Reuther 1970)

The following day (12 March), he recorded: 'I was in the camp again this evening with the heathen to put the word of God close to their heart' (Reuther 1970).

Two days later (on $14 \mathrm{March}$ ), he witnessed preparations for an 'Emu' ceremony (probably Mindiri) at Lake Allalana:

On Saturday afternoon I went to Ngalangalani on foot with Joseph [Ngantjalina] to preach the word of God to the natives camping there ... On Sunday morning I first had a devotion with those [natives] who had been on the station before and then I visited the shearers who were just ready to make [the ceremony/wima of] Warukati [Emu]. I gathered them and then gave an address on the love of Christ who seeks us and also them. During my talk there was one continually knocking, so that the Emu-making does not stop. Soon three men were sent away, dressed up, so that they could return as Emus. O poor people. God give me the strength of the Holy Spirit to follow these people in all humility and faithfulness. May he also bring the Holy Spirit's reign in His time into the hearts of these poor heathen. (Reuther 1970) 
Throughout Reuther's diary and other records, there is little evidence of his engagement with the everyday life of Dieri people and he seems rarely to have left the station itself. The above are among the few comments he makes about such excursions. It seems that he left such contact to the Dieri evangelist Joseph Ngantjalina, and (after 1894) specifically to Otto Siebert as 'bush missionary'. It seems from these entries that, in the face of an actual ceremony, Reuther proselytises to the participants and then prayed for his own strength and faith to survive the strain and weariness of his task of overcoming heathenism.

\section{Later years}

Reuther laboured at Killalpaninna for 18 years. The early years of a new century had been fraught with financial difficulties and a declining Aboriginal population. Stevens (1994: $158 \mathrm{ff}$.) sets out in detail the disappointments and outright conflicts of Reuther's final year.

When Reuther left Killalpaninna in 1906 he acquired a lease of land from the South Australian Government. About 160 hectares was excised from the Dutton family property, Anlaby, to the west of Eudunda. The Reuther family called their farm 'Gumvale'. It was close to the Lutheran Church at Julia (Rechner 2008: 259, see also p. 235). From here, Reuther served the Point Pass congregation as secretary, treasurer and organist (Scherer 1979: 15). The homestead was a former boundary rider's hut. ${ }^{18}$ Reuther still had to make a living (which he did from wheat and sheep) and support his sons' education back at Neuendettelsau. He spent his entire life enveloped by Lutheranism and its close-knit community. For all his insight into a Dieri view of the land, its cosmogony and its sung manifestation, Reuther never abandoned the faith and pity that had been rung in by the Christmas bells of Nürnberg. 


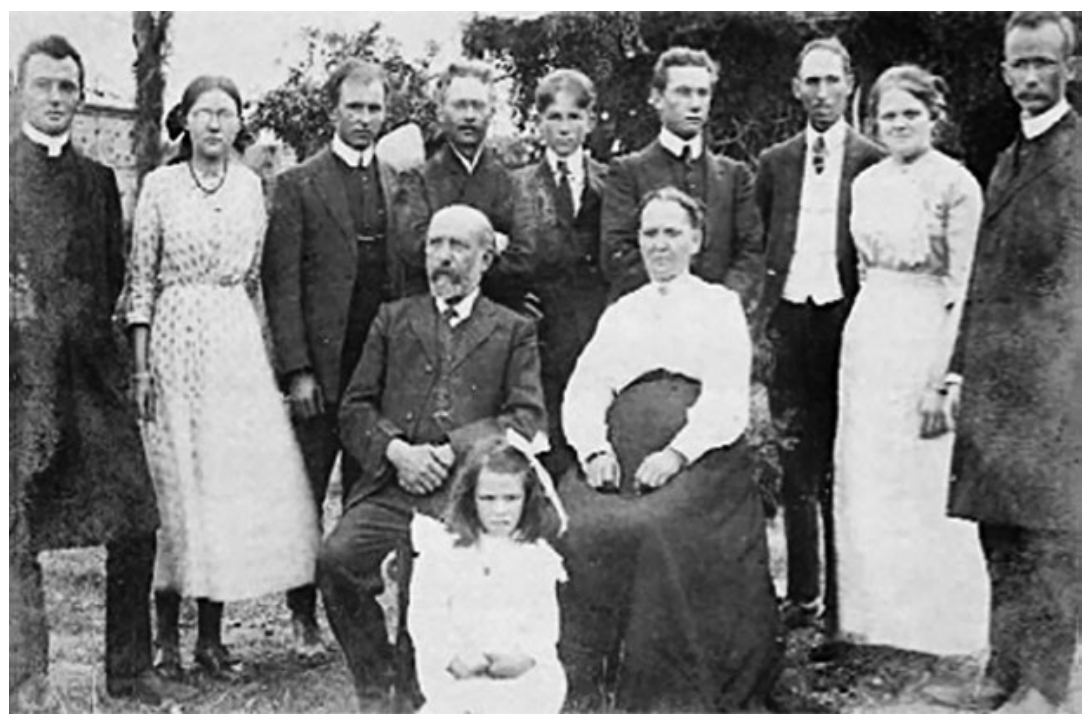

Plate 4.6 J. G. and Pauline Reuther with two Stolz sons, five Reuther sons and only daughter, Alma. Laura Reuther is sitting in the foreground.

Source: Rechner (2008: 235).

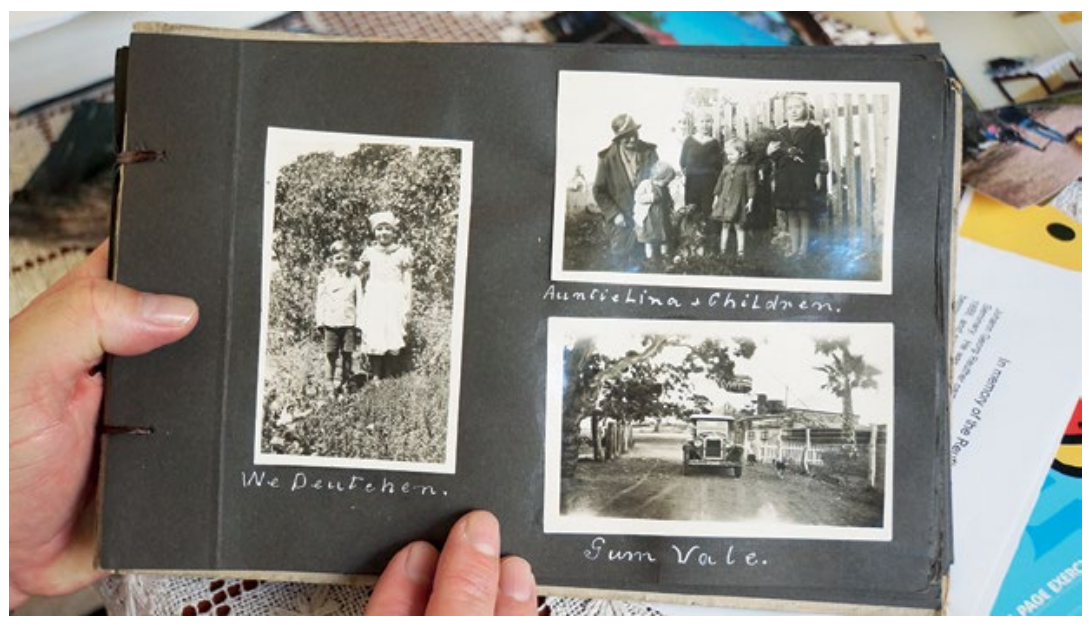

Plate 4.7 Reuther family album from Gumvale, in the possession of Alma's only daughter, Helen Gordon.

Source: Deane Fergie, May 2015. 


\section{Death by drowning}

Reuther's death was as extraordinary as his working life. With a passenger, Reuther was riding in a trap to Hampden Siding to meet his son Martin, who was coming home from Queensland for his parents' silver wedding anniversary. At the Freshwater Ford, the passenger-a Mr Richards with whom Reuther was sharecropping - got out to test the strength of the stream and, as it was fine, they rode on. At the next crossing of Julia Creek, $\mathrm{Mr}$ Richards found the water to be up to his chest. He returned to Reuther in the trap and they proceeded. Witnesses suggested that either the horse was taken from its feet or they entered the Julia not quite at the ford. A flash flood had come downstream and the water in the middle was over the hooded trap. The horse fell and the trap was overthrown. It appears Reuther was kicked in the head by the flailing horse. His body was found 16 kilometres downstream. ${ }^{19}$ The planned anniversary celebration turned into a wake.

Following J. G. Reuther's death in 1914:

the home and wheat farm was managed by mother Pauline with help from ... Oscar, and assistance from Alma and a part Aboriginal girl, Laura, who was always considered part of the family. (Rechner 2008: 267)

Laura Reuther was the daughter of Reuther's Aboriginal housekeeper, Frieda, over whom so much gossip, innuendo and inquiry had taken place in Reuther's final year at Killalpaninna (Stevens 1994: 160). It was rumoured that she was Reuther's child, a point dismissed by Reuther at the time and his descendants today (some of whom knew and lived with Laura well into the twentieth century). Even if she was not his child, Reuther had been chastised by Kaibel, chair of the Mission Committee, for spending too much time in his study and neglecting the moral shepherding of even his own staff: 'you are not leaving your own cell and don't know what is going on at the station. You cannot condone such depravity'. ${ }^{20}$

And, again, in early 1906:

This has gone too far ... In your extensive work that you wish to bring to print ... you have not been driven to further God's word, but to a large extent by your ambition. This immorality has to go to your account. ${ }^{21}$

19 See: The Julia Creek fatality, The Advertiser, [Adelaide], 3 March 1914: 10.

20 Kaibel, letter to Reuther, 7 December 1905, quoted in Stevens (1994: 160).

21 Kaibel, letter to Reuther, 1906, in Stevens (1994: 160). 


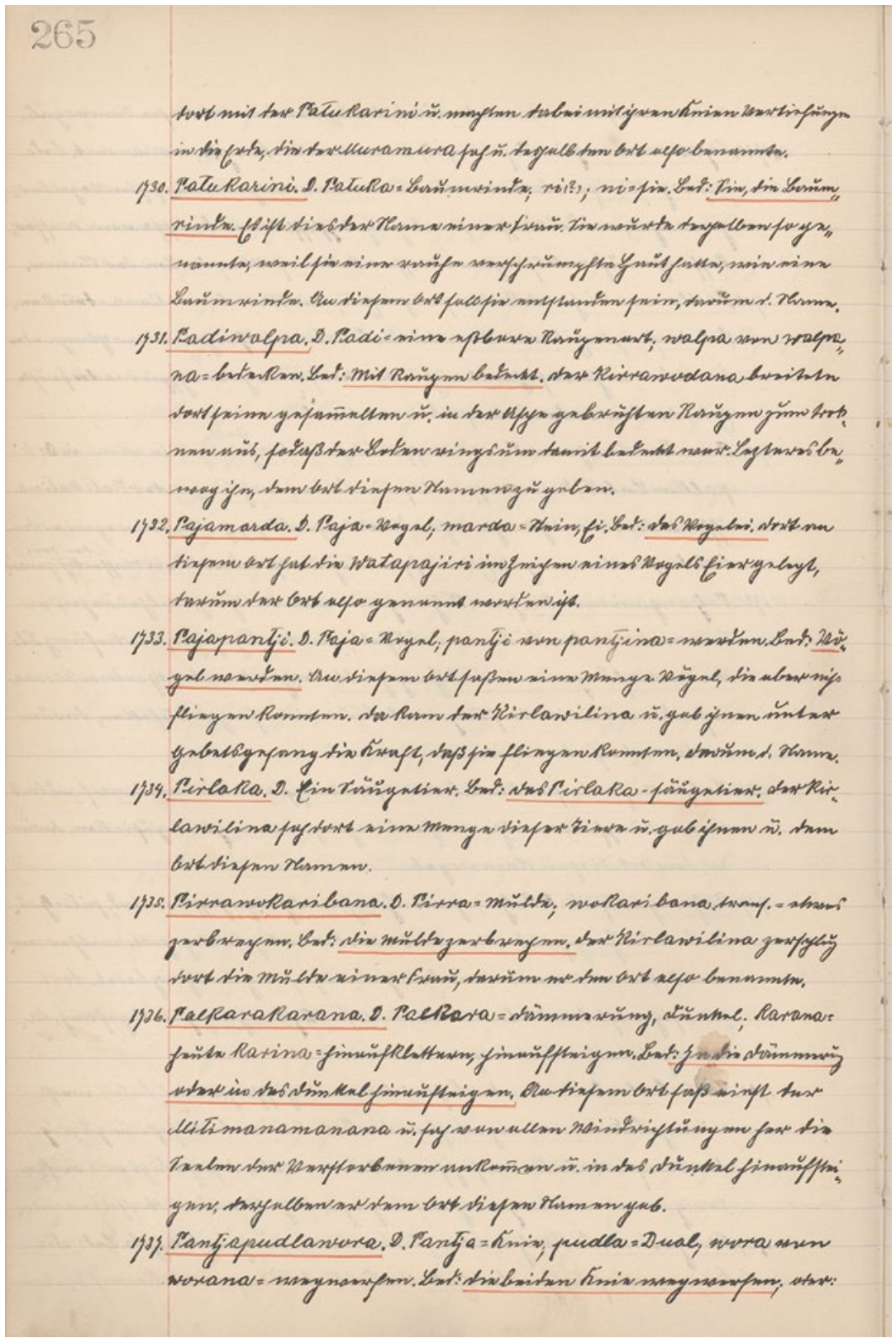

Plate 4.8 Page 265 of Reuther's manuscript of volume 7 titled 'Ortsnamen der Eingeborenen Australiens' ('Placenames of Aboriginal Australians'), 1905. It contains 2,468 placenames.

Source: South Australian Museum, Adelaide, AA-9-7, p. 265. 
Here, Reuther's sheltering the all too human results of moral impropriety and his ethnographic collecting were conflated to condemn his anthropological work, and had precipitated his retreat from Killalpaninna to a Lutheran enclave on the edge of the Barossa Valley. Laura looked after Pauline Reuther until the latter's death in 1937. She is one of several Dieri descendants (women in particular) who were absorbed into Lutheran families and essentially 'lost' to the Dieri community today. Carl Oscar ('Os') Reuther sold Gumvale during World War II.

Pauline and J. G. Reuther are buried together in the cemetery alongside the former Lutheran church at Julia, South Australia, close to their Gumvale property.

\section{Pulcaracuranie}

Here we examine a process by which Reuther's collection of placenames (and their mapping by Henry Hillier) ${ }^{22}$ has come to inform contemporary Dieri relations to country. We focus on a place, Pulcaracuranie, which marked an axis mundi in the Dieri cosmos, a place to which souls of the dead would travel, drink and ascend to the sky as Muramura had done in the beginning. This place had featured in white exploration of the region, and had been documented by pivotal anthropologists such as Elkin, yet its location had been lost to Dieri descendants. Reuther's detailed records (and a toa sculpture depicting the place), together with a triangulation of historical sources, allowed for its relocation and a renewed ascription of meaning.

The placename 'Palkarakarani' is shown on Hillier's map ${ }^{23}$ in association with the edge of the flood-out of Cooper Creek on the western side of the 'Pulcaracuranie Flat' of current topographic maps. Goyder's map, which pre-dates the Hillier map by nearly two decades and appears to be its basis, identifies Pulcaracuranie Flat in the same location; Hillier's 'Palkarakarani' is written against this same feature (albeit to the left, presumably to avoid the other placenames along Cooper Creek), suggesting that he and/or Reuther concurred with this location.

22 Harry James Hillier arrived at Killalpaninna in June 1892 and stayed for 12 years, becoming especially devoted to J. G. Reuther (Scherer 1966a: 305). He was a gifted draftsman and illustrated Reuther's botanical and ethnographic collections, as well as transferring the placenames to a large linen map.

23 For a detailed account of the map, see Jones (2002). 


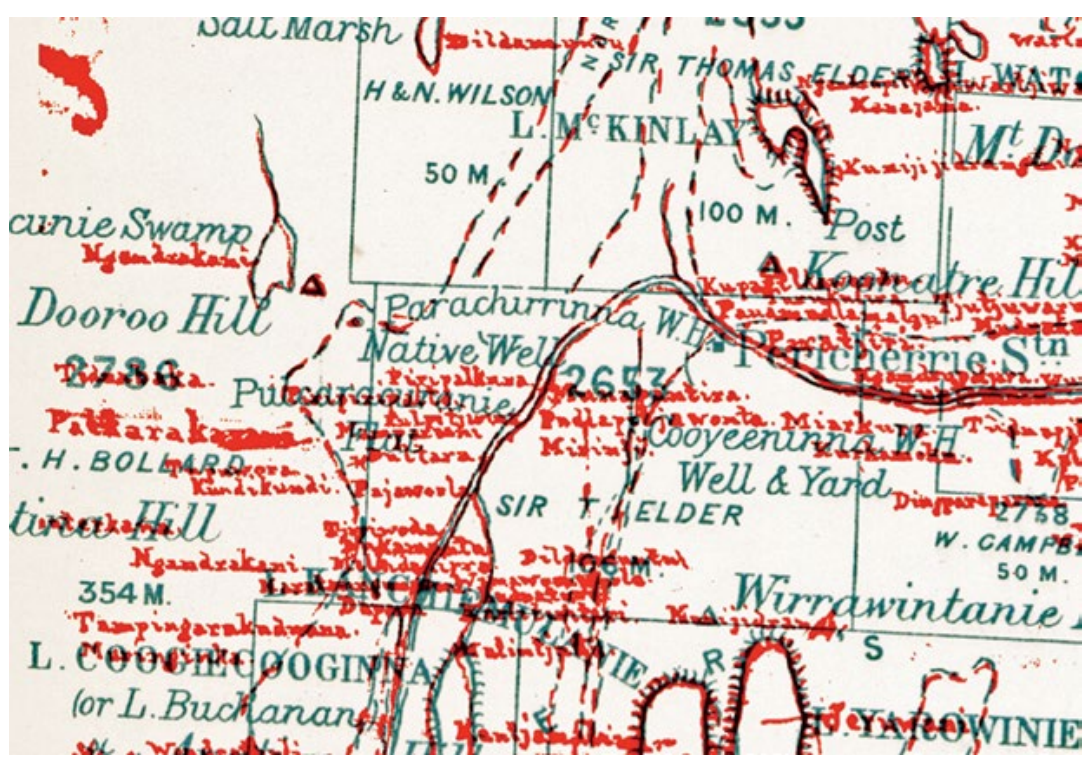

Plate 4.9 A portion of Goyder's Official Atlas of South Australia ... Sheet 5 (1885) overlaid with a portion of Hillier's map (c. 1904) of Reuther placenames (in red) showing a 'native well' at the northern end of Pulcaracuranie Flat.

Source: Compiled by Rod Lucas.

There are acknowledged difficulties in using the Hillier map of Reuther's names to identify places on the ground. In particular, it is often difficult to locate precisely what is being named on Hillier's map itself. As Hercus and Potezny (1991: 148) note:

$[S]$ ince there is no dot to show the precise point, we cannot know whether the place is to be found near the centre, near the beginning, or at the end of the written name.

This makes the precise location of placenames almost impossible to determine without extra information such as Reuther's accompanying descriptions, correlations with other maps, Aboriginal knowledge, field observations, archival references and so on (see Jones 2002: 194).

Neither Reuther nor Hillier is known to have travelled to this part of Cooper Creek and they are unlikely to have had any precise knowledge of the location of 'Palkarakarana' on the ground. Nor does Reuther record any specific physical or topographical features that might distinguish his 'Palkarakarana' or 'Palkarakarani'. 


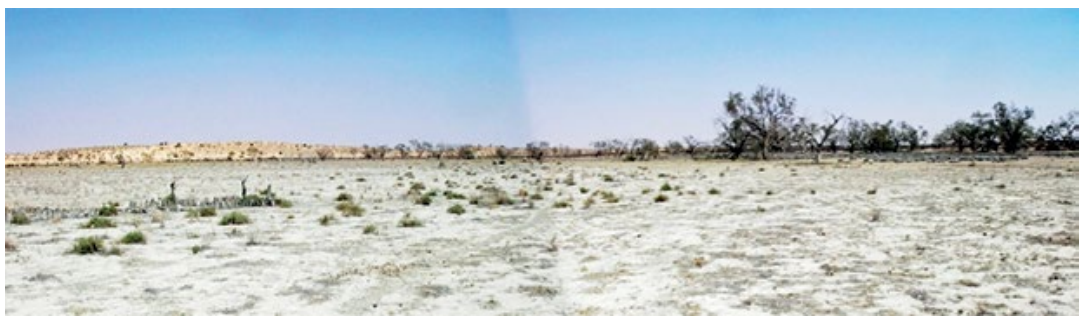

Plate 4.10 Pulcaracuranie, view north-west. The yellow sand dune at back left is likely the one climbed by the explorer John McKinlay in 1861 during his search for Burke and Wills.

Source: Rod Lucas, 2004.

On Wednesday, 27 November 1861, explorer John McKinlay wrote of travelling to:

Pal-coor-a-ganny. At present this is the dry bed of a small lake with plenty of dry clover and grasses in the dry bed. On the north-east side of the lake is a well dug by the natives about ten to eleven feet deep with about one foot of water at present in it and good. I suppose a considerable quantity could be had if the hole were enlarged. Close by there was an encampment of blacks, in all about a dozen, not the same apparent well-fed fellows that frequent the lakes and main creeks. From inquiry it appears that during the dry season this is the sort of water they have to depend upon, and I think the wells are few and far between. A high sandhill was some little distance off and to it I went; from the top of which I had an extensive view. Could see nothing northward and westward but a jumble of lower sandhills looking very dreary without even a creek with its timber to break the monotony of the view. ${ }^{24}$

Field inspections confirm the accuracy of McKinlay's 1861 description of a small lake covered in dry clover and grasses; there is a conspicuous high sand dune to the north-west (reminiscent of the one McKinlay climbed and positioned to see the topographic features he described) and an Aboriginal camp to the north-east (evidenced today by a range of archaeological materials including stone artefacts, scarred trees, hearths and human burials).

Dieri people visited the Pulcaracuranie area within the Dieri \#1 native title claim area for Work Area Clearance (WAC) surveys in November 2003 and again in November-December 2004. A further survey of this 
area was undertaken in August 2006 in respect of proposed petroleum wells on the edges of Pulcaracuranie Flat. In that context, the historical and anthropological records relating to the area became relevant to decision-making about the protection of Aboriginal heritage in the area. Reuther's mythological data, his placename record and the Hillier map became central to this assessment. Further Dieri WAC teams visited the area again in November and December 2006.

A distinctive form of vegetation on the north-eastern edge of the dry lake is indicative of a source of water where none is obvious - something that early pastoralists also seemingly took advantage of with the construction of a water 'whim' or 'race' on this same north-east corner. Dieri representatives identified sedges, a type of 'couch' grass and Trichodesma zeylanicum (water bush) —all found at this location—as growing only where there is water. Dieri have thus viewed this vegetation as suggesting the location of a former 'native well'.
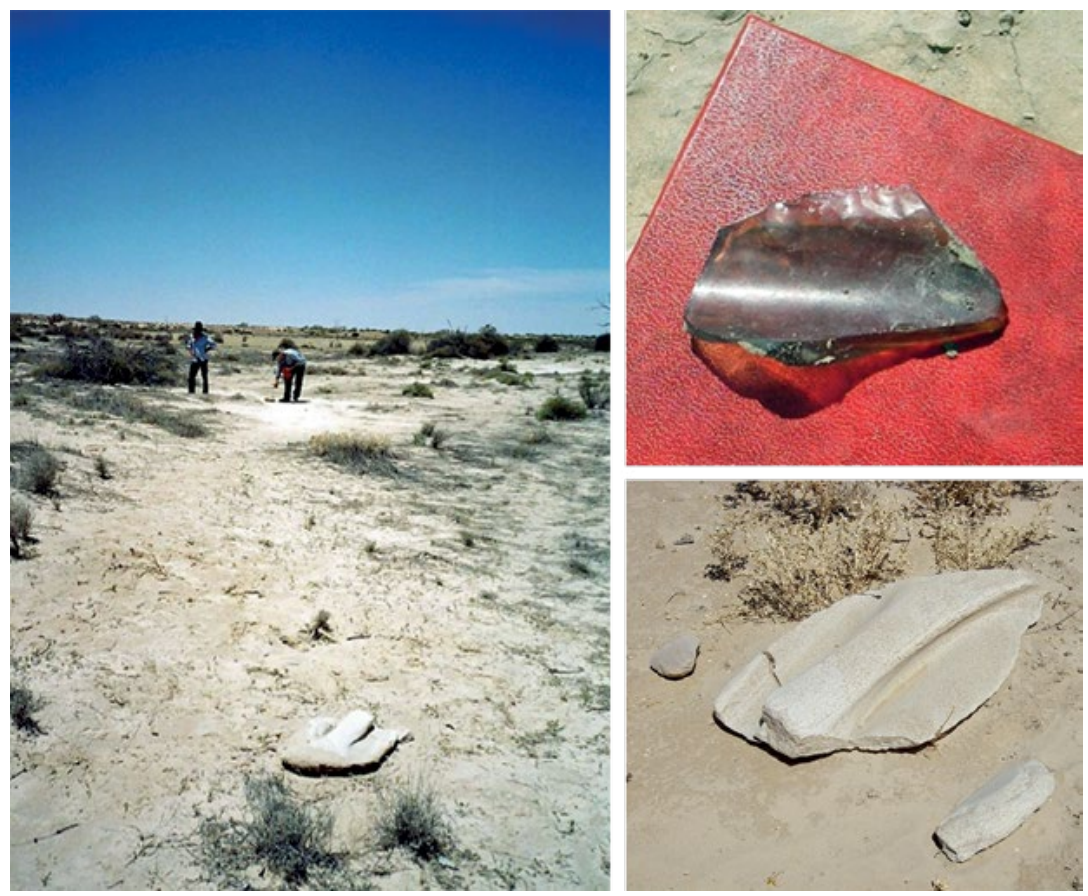

Plates 4.11a-c Artefacts at the Pulcaracuranie campsite, including grinding stones and worked glass.

Source: Photographs by Deane Fergie, Andrew Nettlefold and Jan Scott, December 2006. 
The associated campsite area is extensive, contains an array of artefacts (stone tools, grinding stones, hearths, skeletal remains) and extends from pre-settlement into settlement times (as evidenced by the presence of worked glass) (see Plates 4.11a-c).

Reuther's extensive manuscripts contain various references to Pulcaracuranie. Here we re-present just a few, which are also indicative of the cultural richness to be found throughout his corpus:

\section{Reuther place name material ${ }^{25}$}

No. 1736 Palkarakarana, D[ieri] Palkara = 'twilight, dawn, dusk; darkness'; karana— (nowadays karina) = 'to climb upwards; to ascend.' Meaning: 'to ascend in the twilight or darkness'

Once, as he was camped at this spot, Mit[j]imanamanana saw the souls of the departed arriving from all points of the compass, and ascending upwards in the darkness. He therefore gave the place this name.

\section{Reuther dictionary entry ${ }^{26}$}

1520. Mura (n, m) = 'the deity'

(16) ... The soul ascends in Palkarakarani, where the souls ('heart of the deity') of the muramuras once ascended. At the grave the soul's ceremonial song is sung to it, so that it may accompany it [on its last journey].

1522. muramura ( $n, m \& f) \ldots$ The souls of the deceased muramuras rose heavenward at Palkarakarani, and [today] many of them shine resplendently in the vault of heaven as stars in the constellations. Even the sun and moon are the souls of one-time muramuras.

Other 'Dictionary' entries include:

1634. mungara $(\mathrm{n}, \mathrm{m})=$ 'the soul. ${ }^{27}$

I. Murangara as heart of the deity. With this meaning the legend is in agreement. In the beginning there lived on earth only the muramuras, that is, the demi-gods, the progenitors, the primeval ancestors. These were mortal human beings, but were brought into existence by the Mura 'deity'. 
While Kakalbuna was [once] sitting at Palkarakarani-he was a muramura-he saw the souls of the muramuras who had just recently died winding their way upwards from this place; whereupon he remarked: "'Those are muramura-ngaras ("the hearts of the tribal ancestors").' From here the term mungara takes its origin.

\section{Scherer Vol 2}

813. mungara $(\mathrm{n}, \mathrm{m})=$ 'soul'

2) nauja mungara ngakani, nauja ngani mungara narini puntila nganai ja Palkarakarini palkarakarala nganai = he soul mine, he I soul in death go away will (leave) and in Palkarakara upwards ascend will, i.e. 'this is my soul; [when my soul departs in death] I will make my upward ascent in Palkarakarani'

Shortly prior to death the soul, since it cannot endure physical pain leaves the body and wanders southward. For this reason all 'native' people are buried with the head facing south. Without the soul, the body may still live on for some time, but [eventually] it must die.

Soon after the body is dead, it is buried. The soul turns around to watch its body being buried, and when it sees the latter being carried to the grave on the head [of two people], it says to itself: ngakani palkuni kawalka mapateriji $=$ 'the crows are gathering around my body'.

The soul now turns towards Palkarakarani, where it ascends upward.

There are other references to Pulcaracuranie in Reuther's manuscripts. In Volume 11, for example, Reuther recorded the following in the context of discussing illness:

The fact is, it was here that the muramura Balungopina saw the souls of the various muramura winding their way, in spiral fashion, upward on something in the twilight. [Just] as the souls of the muramura wended their way upward here at Palkarakarani, so, it is believed, all the souls of men will go that way ...

Already while he is sick, the Aboriginal [man] frequently arranges for his ceremonial mura-songs to be sung to him. Thereby he consoles himself in his suffering. With the same ceremonial mura-songs [his] soul is accompanied to Palkarakarani. ${ }^{28}$

28 Reuther's volume 11 (SAM AA266/09/11); Scherer's translation, volume XI. 
Finally, in his volume on toas, Reuther notes that 'Palkarakarani' was a place of paramount importance to traditional Aboriginal people. The passage of souls between earth and sky was represented in a toa sculpture that depicts these two fundamental dimensions of the Dieri universe and their connection at the place called 'Palkarakarani' (toa number 145 in the catalogue by Jones and Sutton 1986: 99; Reuther \#190):

Toa 190 (630) Palkarakarani

Meaning: 'to ascend in the dark.'

With respect to the religion of the Aborigines, this is the most important place [of all], and so we must go into the matter a little more closely.

Palkara signifies 'twilight, dusk;' ngalpura = 'dark' [or darkness], and paratji = 'light.' Palkara is the light of dusk [or the gloaming], and karani from karana means to climb up on something, e.g. on to a tree,-but not to fly up or lift oneself up without some [visible] means. The word therefore signifies: 'to climb up on to something in the twilight.' This much the Aborigine does know: that here the souls of the dead from all points of the compass wend their way ('climb') upwards.

Here the muramura Milkimadlentji (meaning 'evil eye') and Mitjimanamana saw, in their mind's eye, the souls of the dead climbing upwards ...

The white [section] at the lower end of the toa indicates the earth, and the recessed [portion] the atmospheric region between earth and heaven. The upper white [section] denotes the heavens which surround us. The [white] vertical lines are the souls of the dead, as they climb upwards.

The dots above the upper white [section] are the stars. Beyond the stars the local pagan knows of no [further] space. For him, the stars are the souls of the dead, the most pre-eminent of these being those of the muramuras, as he tries to explain this in [the case of] the constellations.

The toa intends to say: 'We have gone to the place where the souls of the dead climb upwards [in the dark]. ${ }^{29}$

29 Reuther, The Diari, vol. XII, 1976-77: 100-1 [SAM AA266]; see also vol. XIII, 1976: 92. 


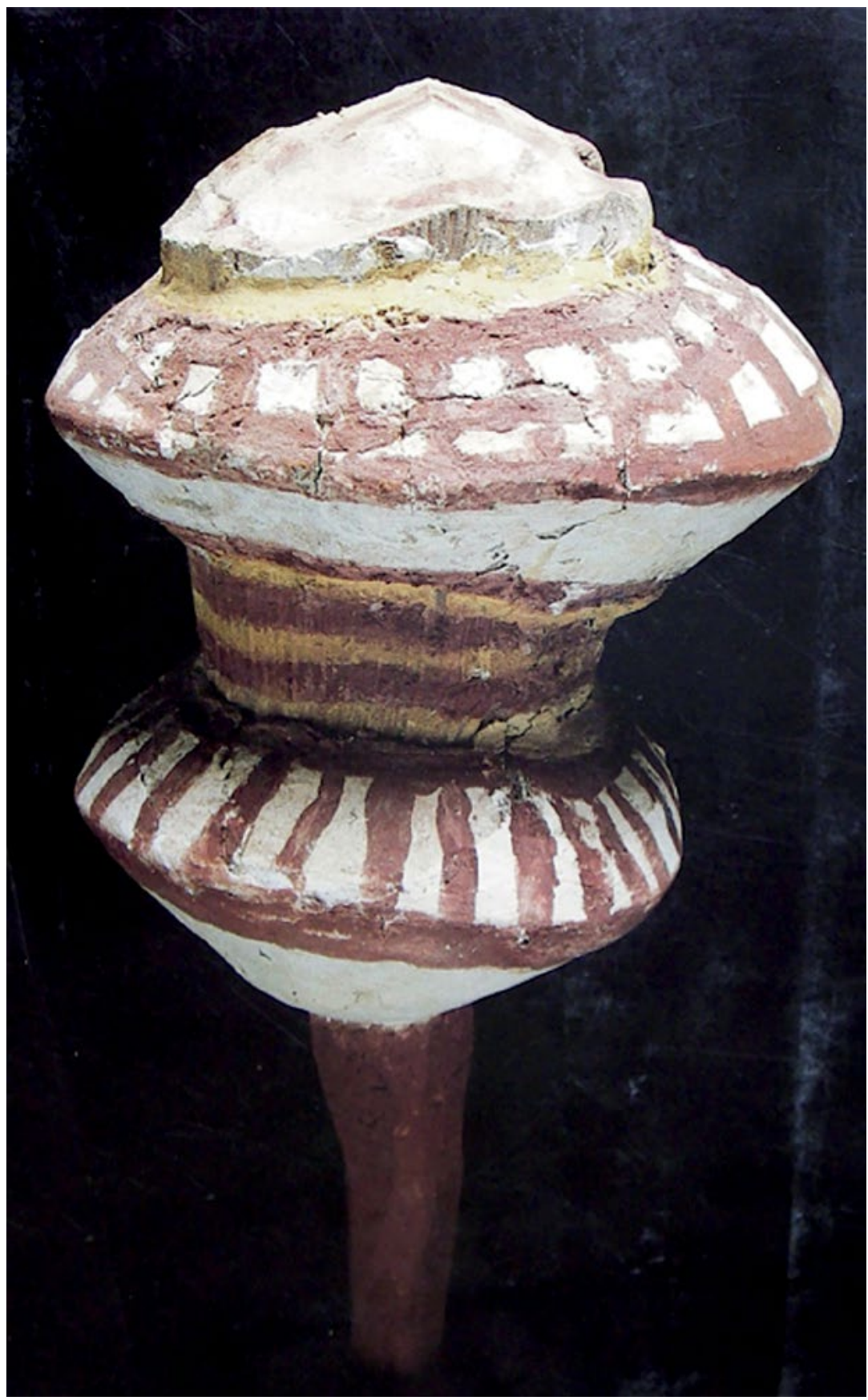

Plate 4.12 Pulcaracuranie (Palkarakarani) toa.

Source: Jones and Sutton (1986: 99). 
Reuther's material includes a number of placenames-Palkarakara, Palkaratarana, Palkarakarana, Palkarakarani-which could be said to confuse any issue of location. The last two forms, however, are the most common and Reuther himself accounts for their correlation on linguistic grounds. Similarly, there are a number of muramura associated with the mythology recorded by Reuther: Balungopina, ${ }^{30}$ Mitjimanamanana, ${ }^{31}$ Kakalbuna $^{32}$ and Milkimadlentji. ${ }^{33}$ These multiple associations (or the relationship between these muramura) are uncommented on and unexplained by Reuther.

Verifying the location of Pulcaracuranie on the ground is, however, made easier by a number of other records, including McKinlay's diary and other ethnographic materials recorded by Otto Siebert.

In a collection of 'legends and customs' published in German in 1910, missionary Siebert ${ }^{34}$ noted the following in respect of the three Dieri souls, kutchi, mungara and jaola:

Of the mungara, the Dieri say that it may go after death southward, but there it continually wanders around in order to see how they bear the corpse to the grave. Jaola is the personal ghost. The jaola goes after death first of all to Palankarani, a place not far from Lake Hope where the ground is much cracked and full of holes; from that place, it goes to heaven, Pariwilpa, and is seen as a shooting star.

'Woe! Who has died?' they say if a shooting star is seen.

Siebert refers to 'Palankarani' as a place where the ground is cracked, broken up or full of holes. Reuther's material does not include such a topographical association. But this is an apt description of parts of the Pulcaracuranie Flat where the occasional floods have left deep 'crabholes'. These are physically distinctive and quite unlike the 'crab-holes' of Bulpanie to the south, for example.

\footnotetext{
30 Reuther's volume 11 (SAM AA266/09/11); Scherer's translation, volume XI.

31 Reuther's volume 7 (SAM AA266/09/7) and volume 13 (SAM AA266/09/13); Scherer's translation, volume VIIB and volume 13 .

32 Reuther's volume 3 (SAM AA266/09/3); Scherer's translation, volume IIIA, word \#1634.

33 Reuther's volume 12 (SAM AA266/09/12); Scherer's translation, volume XII.

34 Siebert is acknowledged to have been dedicated to the collection of information from Aboriginal people associated with the mission - so much so that he was reprimanded by the Mission Committee for his ethnographic work in collaboration with Howitt. Siebert, Letter to Howitt, 27 February 1900, Howitt Papers, Box 3, Folder 1, State Library of Victoria, Melbourne.
} 
Others have collected material about Pulcaracuranie, including A. P. Elkin, who conducted fieldwork throughout north-east South Australia in 1930. He later published an article summarising traditional beliefs and practices connected with death throughout South Australia, based on his own and others' work. This article refers to 'Bälkärakärinyi' or 'Palankarani' as a place associated with those beliefs. Referring to processes of inquest following a death among the tribes of north-eastern South Australia, Elkin wrote:

[T] he corpse ... is placed across the men's heads. One of the old men then takes two lighted sticks, from fifteen inches to three feet in length, called the kunya, and amidst complete silence calls out the name of the place whither the dead person is going, apparently for the purpose of calling his attention to the inquest rite. The words as given me are: Gäla gala gala gala (wake him, or let him know), Bälkärakärinyi (the place), mili waruka (travelling in the air), napa (water), tapari (drink). This Bälkärakärinyi seems to be a spring out west where the spirit has its last drink on its way to the home of the dead. (Elkin 1937: 281)

\section{Conclusions}

A crossreferencing of various historical data on placenames, mythology and geography suggests that the Pulcaracuranie area was a particularly important place in Dieri religion. This importance was reflected in songs and stories relating to the muramura, the ancestral beings who created the landscape and shaped much of traditional Aboriginal social life. Correlating the sources on mythology with present-day topography suggests that the Pulcaracuranie area was seen as a passageway between the everyday world in which people lived on the land and a sky world where people's souls were believed to have lived for a time after death.

Triangulating Reuther's mythological materials, McKinlay's geographic description and field observations provides extremely strong evidence that the 'Pulcaracuranie' area-encompassing the Pulcaracuranie Well and Pulcaracuranie Flat of current topographic maps-was a place of paramount significance within Dieri traditions, it being an axis mundi connecting the realms of sky and earth; in effect, a central pillar or pathway of the Dieri cosmos via which human souls were believed to travel between distinct realms of existence. Through this work, some of the difficulties and uncertainties of locating mythology in a particular place can be reduced. 


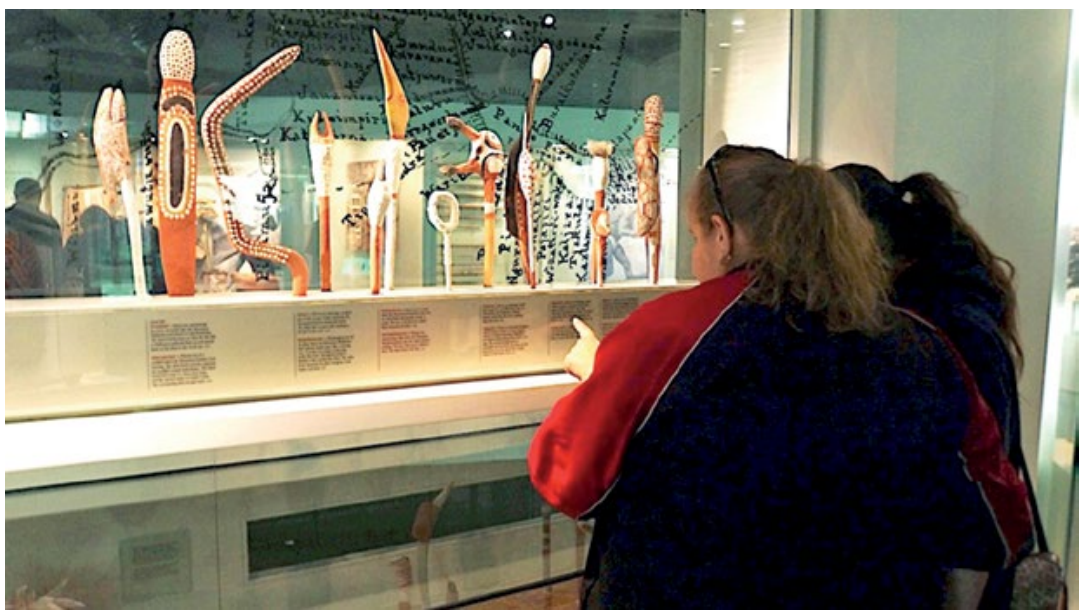

Plate 4.13 Dieri women Melanie Warren and her daughter Jaima Warren viewing toas in the South Australian Museum.

Source: Deane Fergie, 23 July 2014.

But, more importantly, using these materials has allowed contemporary Dieri people to protect important sites and to reconnect with country in ways they have not been able to for several generations. In the process, they are able to use all the materials available to them-from oral history to archival records - to reinscribe the country with meaning.

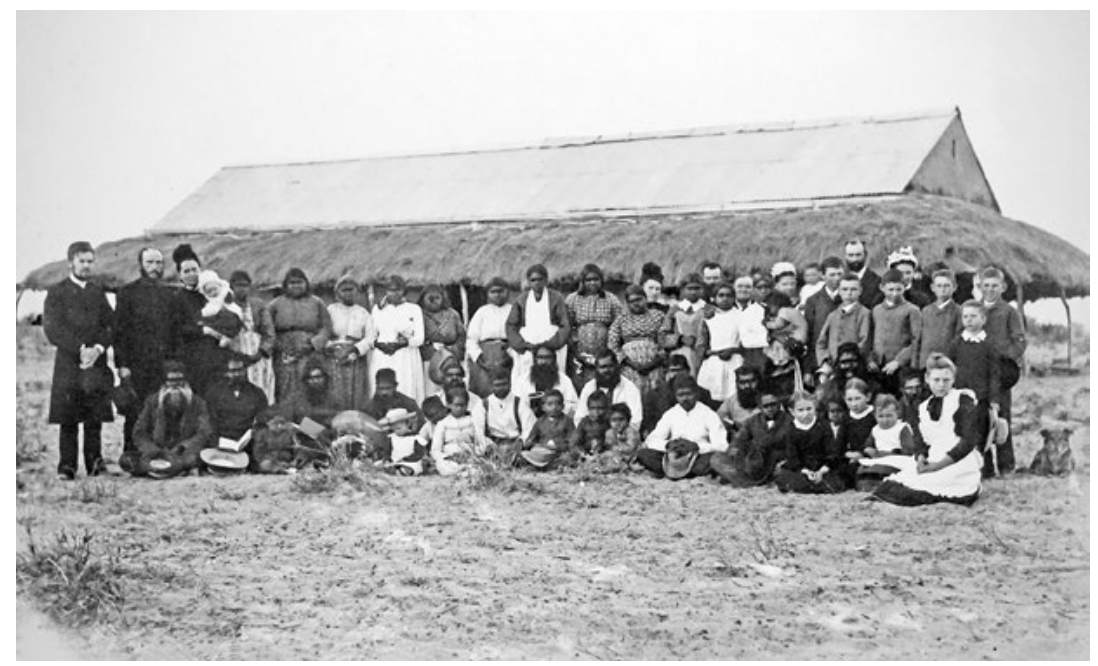

Plate 4.14 Carl Strehlow's farewell from Killalpaninna.

Source: Lutheran Archives. 
Dieri representatives travelled to Canberra in October 2014 to view a range of material culture items and human skeletal remains from their country held in the National Museum of Australia. They talked with museum staff about repatriating the latter. Dieri man Willie Dawson said after viewing these holdings:

We don't know the exact location [from which the human remains came], but I know a location where all the spirits go to at the end of the dayso long as they are back on country that is the best thing for them. ${ }^{35}$

There is talk of returning these human remains to Pulcaracuranie.

\section{References}

Austin, P. 1981. A Grammar of Diyari, South Australia. Cambridge: Cambridge University Press.

Austin, P. 1986. Diyari language postcards and Diyari literacy. Aboriginal History 10(2): 175-92.

Austin, P. 2015. And still they speak Diyari: The life history of an endangered language. Ethnorema 10: 1-17. Available from: www. academia.edu/10050989/And_still_they_speak_Diyari_the_life_ history_of_an_endangered_language, or: eprints.soas.ac.uk/20134/1/ 03\%20Austin.pdf.

Elkin, A. P. 1937. Beliefs and practices connected with death in northeastern and western South Australia. Oceania 7(3): 275-99. doi.org/ 10.1002/j.1834-4461.1937.tb00384.x.

Flierl, J. 1880. Christianieli Ngujangujara-Pepa Dieri Jaurani. Adelaide.

Hercus, L. and Potezny, V. 1991. Locating Aboriginal sites: A note on J. G. Reuther and the Hillier map of 1904. Records of the South Australian Museum 24(2): 139-51.

35 Willie Dawson, personal communication. 
Jones, P. 2002. Naming the dead heart: Hillier's map and Reuther's gazetteer of 2,468 placenames in north-eastern South Australia. In The Land is a Map: Placenames of Indigenous origin in Australia, (eds) L. Hercus, F. Hodges and J. Simpson, pp. 187-200. Canberra: Pandanus Books.

Jones, P. and Sutton, P. 1986. Art and Land: Aboriginal sculptures of the Lake Eyre region. Adelaide: South Australian Museum in association with Wakefield Press.

Kenny, A. 2009. Carl Strehlow's mission. In Migration and Cultural Contact: Germany and Australia, (eds) A. Brandauer and M. Veber, pp. 91-112. Sydney: University of Sydney Press.

Kenny, A. 2017. A preliminary assessment of J. G. Reuther's ethnographic work (1899-1908). LocuSAR report, Adelaide.

Koch, W. and Homann, E. 1870. Nujanujarajinkineixa-Dieri Jaura Jelaribala. Tanunda, SA: Lutheran Mission Committee.

Lucas, R. 1996. The failure of anthropology. Journal of Australian Studies 48: 40-51. doi.org/10.1080/14443059609387265.

McKinlay, J. 1962 [1862]. McKinlay's Journal of Exploration in the Interior of Australia. Melbourne: F. F. Bailliere. [Reprint of Diary of Mr J. McKinlay, Leader of the Burke Relief Expedition, being Journal of Explorations in the Interior of Australia, together with Chart, South Australia, Parliamentary Paper No. 12, 1862. Australiana Facsimile Editions No. 1. Adelaide: Public Library of South Australia.]

Peters, P. W. n.d. The fruits of Luther's mission-mindedness. Wisconsin Lutheran Seminary, Mequon, WI.

Proeve, H. F. W. 1976. Rechner, Gustav Julius (1830-1900). Australian Dictionary of Biography. Canberra: National Centre of Biography, The Australian National University. Available from: adb.anu.edu. au/biography/rechner-gustav-julius-4456/text7261. Published first in hardcopy 1976. Accessed online 10 June 2015.

Proeve, H. F. W. and Proeve, E. H. 1952. A Work of Love and Sacrifice: The story of the mission among the Dieri tribe at Cooper's Creek. Point Pass, SA: E. H. Proeve. 
Rechner, J. G. 2008. G. J. Rechner and His Descendants: Rechner, Fischer/ Fisher, Stolz and Reuther journeys. Adelaide: Self-published.

Reuther, J. G. 1899-1908. Volumes 1-13. SAM AA266/09/1-13, South Australian Museum, Adelaide.

Reuther, J. G. 1970. Diary of J. G. Reuther 1888-1914. Translated by R. B. Reuther. Unpublished ms.

Reuther, J. G. 1981. The Diari. Translated by P. A. Scherer. Microfiche No. 2, Australian Institute of Aboriginal Studies, Canberra.

Reuther, J. G. and Strehlow, C. [translators]. 1897. Testamenta Marra: Jesuni Christuni ngantjani jaura ninaia karitjimalkana wonti Dieri jaurani. Tanunda, SA: G. Auricht.

Scherer, P. A. 1966a. Looking back on a hundred years of Bethesda mission. Lutheran Herald, 8 October: 291, 304-5.

Scherer, P. A. 1966b. Looking back on a hundred years of Bethesda mission. Lutheran Herald, 22 October: 314-15, 317.

Scherer, P. A. 1979. Donor of Aboriginal heritage. The Lutheran 13(12): $12-15$.

Schoknecht, A. C. and Schoknecht, C. P. (compilers) 1997. Missionary Carl Schoknecht, Killalpaninna Mission 1871-1873: Selected Correspondence. Melbourne: Self-published.

Siebert, O. 1910. Sagen und Sitten der Dieri und Nachbarstamme in Zentral-Australien. Globus 97(4): 44-50; 53-9. [English translation held in the Archives of the South Australian Museum, Adelaide.]

Stevens, C. 1994. White Man's Dreaming: Killalpaninna mission 18661915. Melbourne: Oxford University Press.

Strehlow, C. 1907-1920. Die Aranda- und Loritja-Stämme in ZentralAustralien. 7 vols. Frankfurt am Main: Joseph Baer \& Co.

Valleskey, D. J. [1993]. Luther's impact on mission work. Wisconsin Lutheran Seminary, Mequon, WI. Available from: www.wlsessays.net/ bitstream/handle/123456789/1327/ValleskeyLuther.pdf?sequence= 1\&isAllowed=y. Accessed 29 April 2015. 
Veit, W. F. n.d. Labourers in the vineyard or the uneducated missionary: Aspects of the non-theological education of missionaries. Unpublished ms.

Warneck, G. 1897. Evangelische Missionslehre. 3 vols. Gotha: Friedrich Andreas Berthes.

\section{Appendix 4.1: The titles of J. G. Reuther's 13 volumes}

Reuther, J. G. 1904-06. Wörterbuch. Vols 1-4. SAM AA266/09/1-4. South Australian Museum, Adelaide.

Reuther, J. G. 1899-1904. Diari Gramatik, Wörterverzeichnis, Taufordnung etc., Wankaguru-Sprache, Wörterverzeichnis Wonkanguru, luyani Nganmeni, Tirari, Wunkarabana-JaurawurkaJendruwonta-Wonkaranta, Jandruwonta Sprache. Vol. 5. SAM AA266/09/5. South Australian Museum, Adelaide.

Reuther, J. G. n.d. Vol. 6. SAM AA266/09/6. South Australian Museum, Adelaide.

Reuther, J. G. 1905. Ortsnamen der Eingeborenen Australiens. Vol. 7. SAM AA266/09/7. South Australian Museum, Adelaide.

Reuther, J. G. n.d. Bedeutung und Herkunft von Namen der Eingeborenen Australiens. Vols 8 and 9. SAM AA266/09/8-9. South Australian Museum, Adelaide.

Reuther, J. G. n.d. Die Entstehung der Mardu. Vol. 10. SAM AA266/09/10. South Australian Museum, Adelaide.

Reuther, J. G. 1907-08. Von der Götter- und Geisterwelt der Eingeborenen Australiens, Bezeichnung der Toa. Vol. 11. SAM AA266/09/11. South Australian Museum, Adelaide.

Reuther, J. G. 1905. Museum und Toas. Vol. 12. SAM AA266/09/12. South Australian Museum, Adelaide.

Reuther, J. G. n.d. Bedeutung der Toa. Vol. 13. SAM AA266/09/13. South Australian Museum, Adelaide. 
This text is taken from German Ethnography in Australia, edited by Nicolas Peterson and Anna Kenny, published 2017 by ANU Press, The Australian National University, Canberra, Australia.

dx.doi.org/10.22459/GEA.09.2017.04 